\title{
Laboratory studies of the effect of temperature on growth, moulting and reproduction in the co-occurring mysids Neomysis integer and Praunus flexuosus
}

\author{
Gesche Winkler $^{1, *}$, Wulf Greve ${ }^{2}$ \\ ${ }^{1}$ Département de Biologie, Université Laval, Sainte-Foy, Québec G1K 7P4, Canada \\ ${ }^{2}$ Forschungsinstitut Senckenberg, Notkestraße 31, 22607 Hamburg, Germany
}

\begin{abstract}
The growth and reproduction of 2 co-occurring mysids (Neomysis integer Leach, 1814 and Praunus flexuosus F. Müller, 1776) were investigated against the background of their life cycle with individual-based experiments in the laboratory at 2 temperatures $\left(10\right.$ and $\left.15^{\circ} \mathrm{C}\right)$. The response of postmarsupial growth in relation to age in $N$. integer followed a sigmoid curve, based on an increase in both intermoult periods and growth factors. Maturity occurred after 15 to 16 moults and an age of $110 \mathrm{~d}$ at $10^{\circ} \mathrm{C}$. At $15^{\circ} \mathrm{C}$, the mean age was $45 \mathrm{~d}$ and mean length was $8 \mathrm{~mm}$ at maturity. Up to this stage they had moulted 9 to 10 times. In adults, growth rates decreased with increasing length. In post-larval and juvenile individuals of $N$. integer ( 3 to $7 \mathrm{~mm}$ ), growth strongly depended on temperature as shown by high temperature coefficients $\left(Q_{10}=4.0\right.$ to 7.4$)$. The impact of temperature, on the growth of $P$. flexuosus was markedly different, the intermoult periods decreased while the growth factors increased with increasing temperature. At $15^{\circ} \mathrm{C}$ they needed $3.5 \mathrm{mo}$ to mature and averaged 16 to $18 \mathrm{~mm}$. P. flexuosus needed more than twice as long as $N$. integer to reach maturity, long enough for 2 generations of $N$. integer. In addition, temperature coefficients were markedly lower in juvenile $P$. flexuosus $\left(Q_{10}=1.0\right.$ to 3.1) than in juvenile $N$. integer. The reproduction rate of $N$. integer was twice that of $P$. flexuosus. Incubation time for $P$. flexuosus was longer, fewer post-larval individuals emerged, and juveniles were 1 to $1.5 \mathrm{~mm}$ longer than juvenile $N$. integer. There were clear differences in the sequence of generations of $N$. integer and P. flexuosus, based on the development, time to maturity, number, and length of offspring. These interspecific differences in growth and reproduction enable a better insight into the life history strategies of $N$. integer and P. flexuosus and help to interpret the different distribution patterns, population structures, and the coexistence of these 2 species.
\end{abstract}

KEY WORDS: Neomysis integer $\cdot$ Praunus flexuosus $\cdot$ Mysidacea $\cdot$ Growth $\cdot$ Life cycle Resale or republication not permitted without written consent of the publisher

\section{INTRODUCTION}

There are about 780 species of Mysidacea within 120 genera (Mauchline 1980). Mysids are predominantly coastal, shallow water organisms, living in close proximity to the sediment surface. Some species are

*E-mail: gesche.winkler@giroq.ulaval.ca also common in freshwater habitats. Because of their great abundance and widespread distribution in particular environments and their different feeding methods, mysids probably form an important link in marine food webs. They occupy a key position between benthos, plankton and nekton (Mauchline 1980, Fulton 1982a,b).

In the outer part of the Elbe estuary, 6 mysid species are common. Of these, Neomysis integer Leach, 1814 and Praunus flexuosus F. Müller, 1776 dominate the 
shallow waters. They tolerate a broad range of salinity and temperature (Nicol 1935, Kinne 1955, McLusky \& Heard 1971, McLusky 1979). Both species co-occur in the shallow, sublittoral, brackish region of the Elbe estuary near Cuxhaven. This co-occurring distribution is known from the Swedish and Danish coast of the Baltic (Rasmussen 1973), the West Frisian coast (Mees et al. 1993), and the English coast (Mauchline 1971b). In Lough Etive, Scotland, McLusky \& Heard (1971) found a co-occurrence in spring of $N$. integer and P. flexuosus; in summer the populations separated and $P$. flexuosus dominated.

Similar life history traits and omnivorous feeding habits indicate a high niche overlap. Detailed knowledge of the population structure and the life history strategies of Neomysis integer and Praunus flexuosus are necessary to define their position in the community, possible interspecific competition, and other potential interactions between them. Information on growth and moulting is fragmentary. Direct comparative studies have not been made on coexisting populations. Growth curves for mysids have been constructed from field data (Lasenby \& Langford 1972, Mauchline 1977, Childress \& Price 1978, Bremer \& Vijverberg 1982) with much difficulty (Allen 1971, Mauchline 1985). Only Astthorsson \& Ralph (1984) conducted detailed field and laboratory studies on the growth and moulting of $N$. integer in the Ythan estuary, Scotland. Information on growth and reproduction of $P$. flexuosus is scarce from field data (Mauchline 1971b, Astthorsson 1987) and laboratory studies (Petersen 1922, Nouvel \& Nouvel 1939, Astthorsson 1987).

The major objective of this study was to evaluate and compare aspects of the life history of the 2 mysids. Their growth and moulting were investigated in terms of sexual maturity and reproduction. In addition the present paper assesses the interactive effects of temperature, body size and age on the rates of growth and reproduction to gain a better insight into their life history strategies. The interspecific differences which may allow these species to coexist in some environments are described in detail.

\section{MATERIALS AND METHODS}

In the outer Elbe estuary near Cuxhaven, Neomysis integer and Praunus flexuosus were caught by a $1 \mathrm{~m}$ diameter standard plankton net (1000 $\mu \mathrm{m}$ mesh) and a Tucker trawl $(500 \mu \mathrm{m})$ from the RV 'Uthörn' of the Biologische Anstalt Helgoland during 1996 to 1998. The salinity range in this brackish area was between 15 and 20 psu. To minimise damage to the mysids, each haul lasted only 3 to $5 \mathrm{~min}$, after which the mysids were collected in $30 \mathrm{l}$ plastic containers and transported rapidly to the laboratory. In the laboratory the mysids were acclimated in Plexiglas culturing jars. A rotating water jet on top retained any mysid that jumped out of the water. A sand and gravel filter regenerated the circulating water. The mysids were kept in 20 psu seawater at temperatures of 10 and $15^{\circ} \mathrm{C}$. These temperatures were chosen for the growth studies because they are close to the average temperatures in the outer Elbe estuary in spring/autumn and summer, respectively. The mysids were fed with a surplus of newly hatched ( 1 to $3 \mathrm{~d}$ old) Artemia sp. and frozen pieces of mysids.

The experimental studies on growth were carried out in basins holding 15 plastic chambers ( $72 \mathrm{ml}$ each) with water flow circulating up from the bottoms of the chambers, which were fitted with $250 \mu \mathrm{m}$ gauze at the bottom and top. Four basins were connected to a brackish-water circulation system, whereby the water was pumped up to the first basin and flowed sequentially through the following basins, cascading into a sand and gravel filter and subsequently flowing back to the reservoir aquarium. Juveniles, immature and mature mysids from different field collections were kept individually in these chambers. Two experiments at $10^{\circ} \mathrm{C}$ and 3 experiments at $15^{\circ} \mathrm{C}$ were carried out. Up to 60 organisms could be kept under the same experimental conditions during each run. The first $10^{\circ} \mathrm{C}$ growth experiment started with 14 newly hatched Neomysis integer, 20 older individuals of $N$. integer and 22 newly hatched Praunus flexuosus. In the second $10^{\circ} \mathrm{C}$ experiment, the growth of $39 \mathrm{P}$. flexuosus of different ages were observed. In the first $15^{\circ} \mathrm{C}$ experiment, 27 newly hatched $N$. integer and 24 newly hatched $P$. flexuosus were kept in the growth chambers. The second $15^{\circ} \mathrm{C}$ experiment used 30 older $P$. flexuosus, and the third $15^{\circ} \mathrm{C}$ experiment $32 \mathrm{~N}$. integer. The results for each species, if they were not reared at the same time, were pooled in the analysis. The chambers were checked daily for deaths and the presence of moults which were removed and measured by a microscope (type Diavert). Because the moults are fragile and easily deformed, only the exopod of the uropod was retained, and was measured as described by Clutter \& Theilacker (1971). The total length of the mysid was calculated from the relationship between uropod length and body length (Table 1).

Table 1. Neomysis integer and Praunus flexuosus. Relationship between uropod length $(U)$ and body length $(L)$

\begin{tabular}{|lccc|}
\hline Species & $\mathrm{n}$ & $\begin{array}{c}U-L \\
\text { relationship }\end{array}$ & $\mathrm{R}^{2}$ \\
& & & \\
\hline Neomysis integer & 136 & $L=3.856 U+0.91$ & 0.99 \\
Praunus flexuosus & 157 & $L=4.794 U+0.03$ & 0.98 \\
\hline
\end{tabular}


The uropod-length measurements were carried out on individuals collected and anaesthetised by soda water at the same time as the experimental individuals. Following Mauchline (1971a), the body length was taken as the distance from the base of the eyestalk to the posterior end of the exopod of the uropods excluding the setae. The agespecific growth of Neomysis integer and Praunus flexuosus was described in terms of the duration of the successive intermoult periods in days and the growth factor at each moult (percent increase in body size at the moult: Mauchline 1977). Growth rates were calculated as the increase in body size in $\mathrm{mm} \mathrm{d}^{-1}$ within 1 intermoult period. The effect of temperature on post-embryonic growth at 10 and $15^{\circ} \mathrm{C}$ was evaluated by the temperature coefficient $Q_{10}$, defined as follows (Gaudy \& Guérin 1979, Toda et al. 1983):

$$
Q_{10}=\left(\frac{\mathrm{GR}_{T_{2}}}{\mathrm{GR}_{T_{1}}}\right)^{10 /\left(T_{2}-T_{1}\right)}
$$

where $\mathrm{GR}_{T_{1}}$ and $\mathrm{GR}_{T_{2}}$ are growth rates at temperatures $T_{1}$ and $T_{2}$, respectively.

In addition, maturation was determined from the growth experiments using the size and age at which spawning and brooding of eggs and larvae occur in Neomysis integer and Praunus flexuosus.

To measure reproduction, the number of juveniles released was counted. Females with fertilised eggs taken were out of the culturing jars (laboratory generation) and kept individually in 11 beakers. Every other day the water ( $20 \mathrm{psu}$ ) was replaced. The females were fed in the same way as described earlier. As soon as the juveniles emerged, the body length of the female was measured. Incubation time was calculated as the difference between the date of laying eggs in the brood pouch and the date of release of the juveniles from the marsupium. Finally, the mean reproduction rate was calculated by dividing the number of released juveniles by the incubation period in days.

\section{RESULTS}

\section{Comparison of growth curves of the 2 species}

Growth curves of reared Neomysis integer and Praunus flexuosus kept at 10 and $15^{\circ} \mathrm{C}$ were plotted. Observations were made from the egg through the juvenile stages and to maturity. Both species showed distinctly different growth patterns. N. integer at $10^{\circ} \mathrm{C}$ reached maturity after 3.5 mo with a mean length of 8 to $9 \mathrm{~mm}$. In contrast, at $15^{\circ} \mathrm{C}$ development was shortened to 1.5 mo (Fig. 1).

Praunus flexuosus at $10^{\circ} \mathrm{C}$ did not reach maturity during our experiment but after 6 mo they reached a

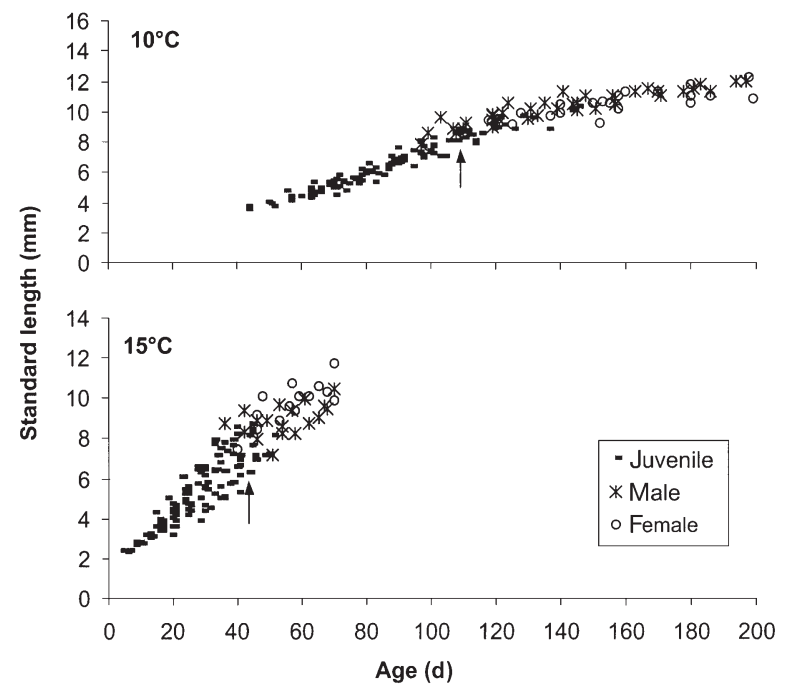

Fig. 1. Neomysis integer. Growth in length of mysids maintained in the laboratory at $10^{\circ} \mathrm{C}(\mathrm{n}=20)$ and $15^{\circ} \mathrm{C}(\mathrm{n}=27)$. Each data point indicates moulting; arrow shows the beginning of maturation

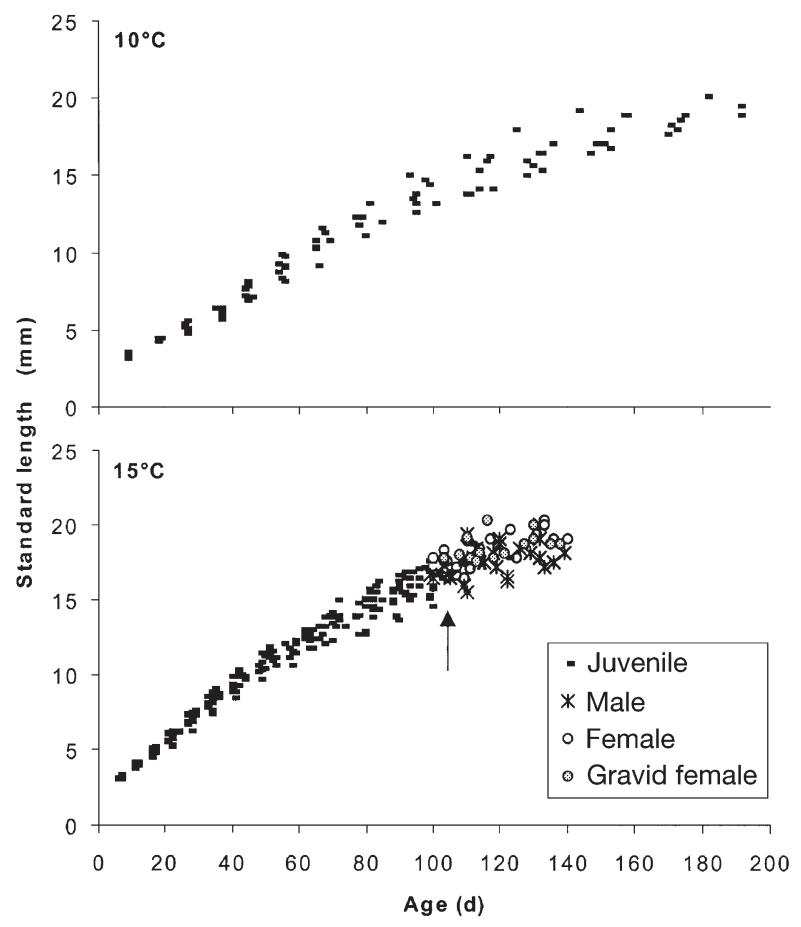

Fig. 2. Praunus flexuosus. Growth in length of mysids maintained in the laboratory at $10^{\circ} \mathrm{C}(\mathrm{n}=22)$ and $15^{\circ} \mathrm{C}(\mathrm{n}=24)$. Each data point indicates moulting; arrow shows beginning of maturation

mean length of 18 to $20 \mathrm{~mm}$. At $15^{\circ} \mathrm{C}$ they required $3.5 \mathrm{mo}$ to mature and averaged 16 to $18 \mathrm{~mm}$ (Fig. 2). At $15^{\circ} \mathrm{C}, \mathrm{P}$. flexuosus needed more than twice as long as Neomysis integer to reach maturity, long enough for 2 generations of $N$. integer. 

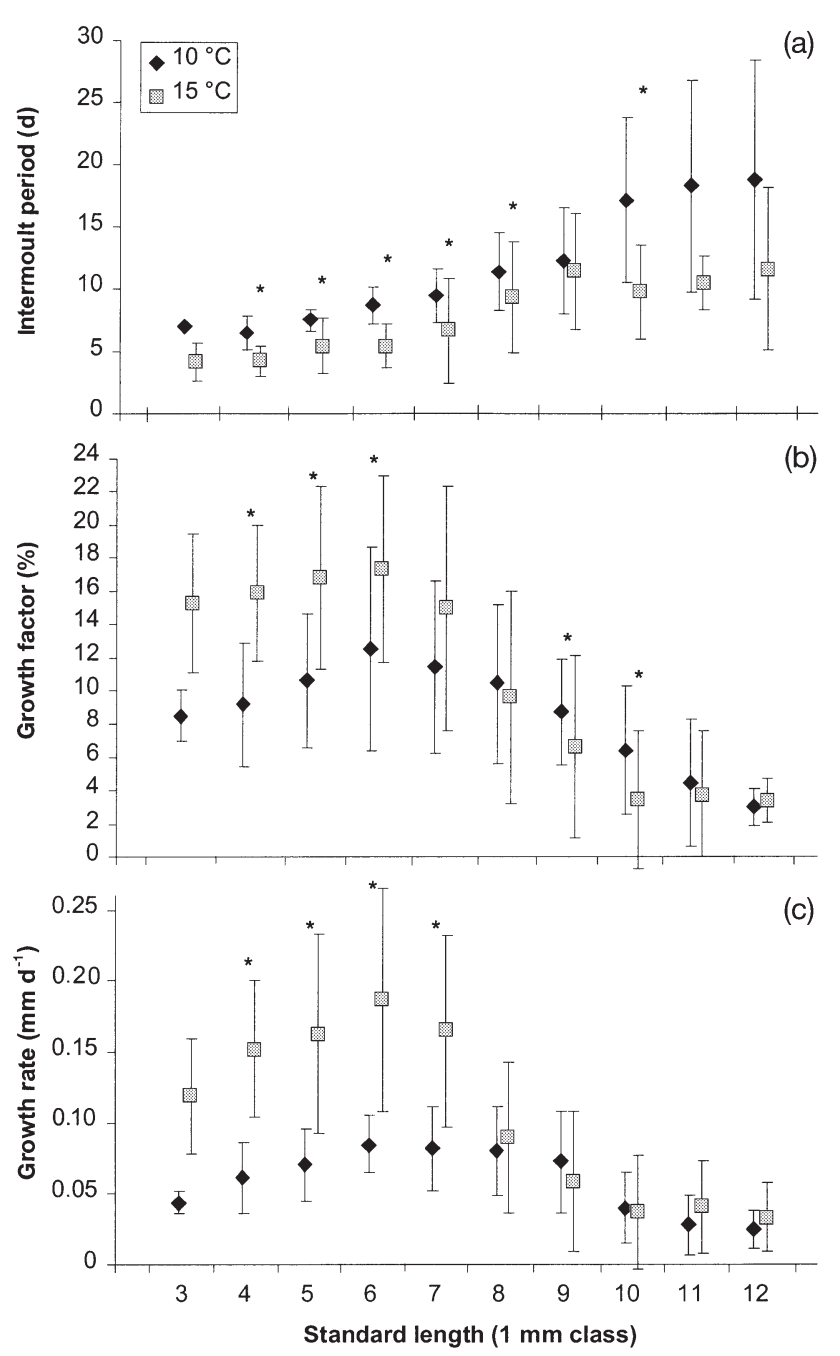

Fig. 3. Neomysis integer. Comparison of (a) mean intermoult period, (b) growth factor and (c) growth rate at $10^{\circ} \mathrm{C}(\mathrm{n}=36)$ and $15^{\circ} \mathrm{C}(\mathrm{n}=59)$ of $1 \mathrm{~mm}$ size classes. Asterisks mark significant differences between both temperatures within 1 sizeclass (Mann-Whitney $U$-test with a significance level of $p \leq 0.05$ )

\section{Growth of Neomysis integer in relation to size and temperature}

Growth of post-larval, juvenile and adult Neomysis integer ( 2 to $12 \mathrm{~mm}$ ) was measured in the laboratory. The duration of successive intermoult periods increased with increasing size of the individuals at both 10 and $15^{\circ} \mathrm{C}$ (Fig. 3a). In most of the length classes, the duration of successive intermoult periods was longer at $10^{\circ} \mathrm{C}$ than at $15^{\circ} \mathrm{C}$. A $4 \mathrm{~mm} \mathrm{~N}$. integer moulted every $7 \pm$ $1 \mathrm{~d}$ at $10^{\circ} \mathrm{C}$ and every $4 \pm 1 \mathrm{~d}$ at $15^{\circ} \mathrm{C}$. Within the $12 \mathrm{~mm}$ length class they moulted every $19 \pm 10 \mathrm{~d}$ at $10^{\circ} \mathrm{C}$ and every $12 \pm 7 \mathrm{~d}$ at $15^{\circ} \mathrm{C}$. The variability within length classes also increased with growth (Fig. 3a).
The growth factor at both temperatures increased during the early stages up to $6 \mathrm{~mm}$ in length and then decreased steadily at larger sizes. In $<6 \mathrm{~mm}$ size classes, the mean growth factor of each class was significantly higher at $15^{\circ} \mathrm{C}$ than at $10^{\circ} \mathrm{C}$ (Mann-Whitney $U$-test, $\mathrm{p} \leq 0.05)$. In contrast, the larger specimens (9 to $10.9 \mathrm{~mm}$ ) showed significantly higher growth factors at $10^{\circ} \mathrm{C}$. Specimens larger than $10.9 \mathrm{~mm}$ showed no differences in growth factors at both temperatures. The maximal mean growth factor occurred in the $6 \mathrm{~mm}$ size class with an increase of $4 \%$ from $13 \pm 6 \%$ at $10^{\circ} \mathrm{C}$ to $17 \pm 6 \%$ at $15^{\circ} \mathrm{C}$ (Fig. 3 b).

The growth rate in relation to size showed a more distinctive curve at $15^{\circ} \mathrm{C}$ (with a maximum in the $6 \mathrm{~mm}$ size class of $0.19 \pm 0.08 \mathrm{~mm} \mathrm{~d}^{-1}$ ) than at $10^{\circ} \mathrm{C}$ (with a maximum in the same size class of $0.09 \pm 0.02 \mathrm{~mm} \mathrm{~d}^{-1}$ ). The mean growth rate of juveniles was significantly higher at $15^{\circ} \mathrm{C}$. No differences were observed in the mean growth rate of larger specimens (Fig. 3c).

The growth of Neomysis integer is characterised by increasing successive intermoult periods. For individuals at $10^{\circ} \mathrm{C}$, the time interval between 2 moults was longer than at $15^{\circ} \mathrm{C}$. The growth factor increased at the beginning of postmarsupial development, and then declined from maturity on. Growth factors at $10^{\circ} \mathrm{C}$ were lower than at $15^{\circ} \mathrm{C}$ until the mysids reached a size of $7 \mathrm{~mm}$, when the trend reversed. The mean growth rate of small $N$. integer increased with increasing size but slowed down as development proceeded. Significant differences in growth rates were only found in small $N$. integer, in which the growth rates were higher at $15^{\circ} \mathrm{C}$ than at $10^{\circ} \mathrm{C}$. Large individuals grew with similar growth rates at both temperatures.

\section{Growth of Praunus flexuosus in relation to size and temperature}

The duration of the intermoult period for Praunus flexuosus depended on both the length of the mysid and the temperature at which it was growing. Fig. 4a shows that the duration of the intermoult periods increased with increasing specimen size and was significantly longer at the colder temperature. The duration of intermoult periods at $10^{\circ} \mathrm{C}$ ranged from $9 \pm 2 \mathrm{~d}$ in the $3 \mathrm{~mm}$ length class to $29 \pm 8 \mathrm{~d}$ in the $23 \mathrm{~mm}$ class, and at $15^{\circ} \mathrm{C}$ lasted $5 \pm 0.5 \mathrm{~d}$ in post-larval mysids and $20 \pm 3 \mathrm{~d}$ in mysids measuring $23 \mathrm{~mm}$ (Fig. 4a).

There was also a significant difference in growth factors between temperatures, with mean growth factors higher at $10^{\circ} \mathrm{C}$ than at $15^{\circ} \mathrm{C}$. As size increased, growth factors decreased, from $29 \pm 6$ to $3.0 \pm 3.1 \%$ at $10^{\circ} \mathrm{C}$ and from $21 \pm 4$ to $1.3 \pm 0.2 \%$ at $15^{\circ} \mathrm{C}$ (Fig. $4 \mathrm{~b}$ ).

The maximum growth rate of Praunus flexuosus at both temperatures occurred when the mysids reached 
a size length of 7 and $5 \mathrm{~mm}$ at 10 and $15^{\circ} \mathrm{C}$, respectively. The difference in growth rates at both temperatures was significant as postmarsupial development began (Mann-Whitney $U$-test, $\mathrm{p} \leq 0.05$ ). Larger individuals $(>17 \mathrm{~mm}$ ) did not show any difference. Praunus flexuosus grew at a maximal mean growth rate of 0.14 $\pm 0.05 \mathrm{~mm} \mathrm{~d}^{-1}$ at $10^{\circ} \mathrm{C}$ and of $0.17 \pm 0.05 \mathrm{~mm} \mathrm{~d}^{-1}$ at $15^{\circ} \mathrm{C}$, with significantly lower growth rates in larger individuals (17 to $23 \mathrm{~mm}$ : Fig. 4c).

The following growth patterns were found for Praunus flexuosus: post marsupial juveniles were $3.5 \mathrm{~mm}$, during development the duration of intermoult periods increased, and the development period lasted longer at colder temperatures. On the other hand the growth factors decreased with increasing size, and at $10^{\circ} \mathrm{C}$ the growth factors were greater than at $15^{\circ} \mathrm{C}$. The growth rate in relation to size is described by a curve, with a maximum at a size of $7 \mathrm{~mm}$ at $10^{\circ} \mathrm{C}$ and of $5 \mathrm{~mm}$ at $15^{\circ} \mathrm{C}$, but small individuals grew faster at $15^{\circ} \mathrm{C}$ than at $10^{\circ} \mathrm{C}$, although no differences were found at either temperature for larger individuals $(>17 \mathrm{~mm})$.

\section{$Q_{10}$ values}

To compare the effect of temperature on growth of both species, the temperature coefficient $Q_{10}$ was cal-

Table 2. Neomysis integer and Praunus flexuosus. Relationship between growth rate and temperature, expressed as the temperature coefficient $Q_{10}$

\begin{tabular}{|c|c|c|c|}
\hline \multirow{2}{*}{$\begin{array}{l}\text { Species, } \\
\text { Class }\end{array}$} & \multicolumn{2}{|c|}{ Growth rate $\left(\mathrm{mm} \mathrm{d}^{-1}\right)$} & \multirow[t]{2}{*}{$Q_{10}$} \\
\hline & $10^{\circ} \mathrm{C}$ & $15^{\circ} \mathrm{C}$ & \\
\hline \multicolumn{4}{|c|}{ Neomysis integer (1 mm size class) } \\
\hline 3 & 0.044 & 0.119 & 7.34 \\
\hline 4 & 0.062 & 0.152 & 6.13 \\
\hline 5 & 0.071 & 0.163 & 5.28 \\
\hline 6 & 0.085 & 0.187 & 4.83 \\
\hline 7 & 0.082 & 0.165 & 4.02 \\
\hline 8 & 0.080 & 0.089 & 1.24 \\
\hline 9 & 0.073 & 0.059 & 0.66 \\
\hline 10 & 0.040 & 0.037 & 0.88 \\
\hline 11 & 0.028 & 0.040 & 2.11 \\
\hline 12 & 0.025 & 0.033 & 1.82 \\
\hline \multicolumn{4}{|c|}{ Praunus flexuosus (2 mm size class) } \\
\hline 3 & 0.104 & 0.155 & 2.21 \\
\hline 5 & 0.096 & 0.170 & 3.11 \\
\hline 7 & 0.136 & 0.168 & 1.53 \\
\hline 9 & 0.134 & 0.153 & 1.30 \\
\hline 11 & 0.115 & 0.115 & 1.00 \\
\hline 13 & 0.081 & 0.109 & 1.83 \\
\hline 15 & 0.070 & 0.092 & 1.70 \\
\hline 17 & 0.061 & 0.059 & 0.93 \\
\hline 19 & 0.044 & 0.034 & 0.58 \\
\hline 21 & 0.039 & 0.030 & 0.61 \\
\hline 23 & 0.025 & 0.029 & 1.33 \\
\hline
\end{tabular}
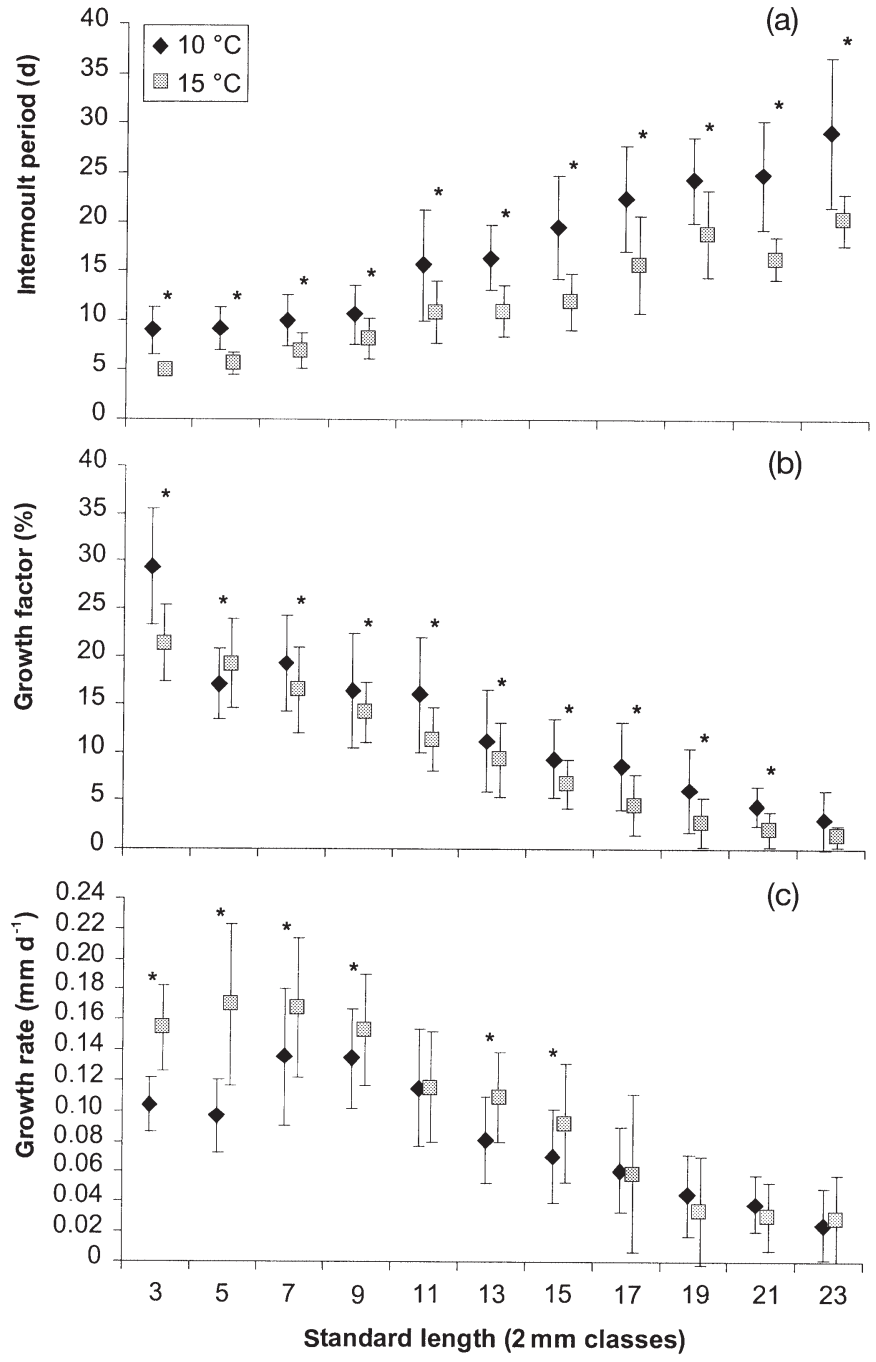

Fig. 4. Praunus flexuosus. Comparison of (a) mean intermoult period, (b) mean growth factor and (c) mean growth rate at $10^{\circ} \mathrm{C}(\mathrm{n}=61)$ and $15^{\circ} \mathrm{C}(\mathrm{n}=54)$ of $2 \mathrm{~mm}$ size classes. Asterisks mark significant differences between both temperatures within 1 size class (Mann-Whitney $U$-test with a significance level of $\mathrm{p} \leq 0.05$ )

culated. In both species the temperature coefficient decreased with increasing size, even though Neomysis integer had a much higher $Q_{10}$ value than Praunus flexuosus of corresponding size. $Q_{10}$ values for $N$. integer peaked in the $3 \mathrm{~mm}$ size class at 7.3, whereas $Q_{10}$ values of $P$. flexuosus ranged from 0.58 to 3.11 (Table 2).

\section{Reproduction}

In order to characterise reproduction, 2 components were investigated: incubation time and the quantity of reproductive process. Incubation time is defined as the 


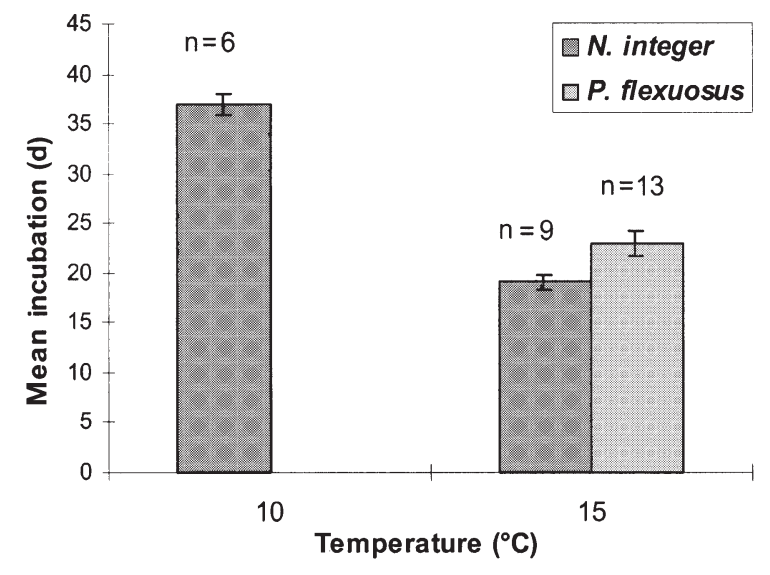

Fig. 5. Neomysis integer and Praunus flexuosus. Mean incubation time (d) of mysids maintained at 10 and $15^{\circ} \mathrm{C}$

developmental time within the marsupium, while the quantity of reproductive process is the number of juveniles released from a female's marsupium at one time. Temperature had a strong effect on marsupial development from the egg to the post-larval stage in Neomysis integer. At $10^{\circ} \mathrm{C}$ the mean incubation time was nearly double that at $15^{\circ} \mathrm{C}$ (Fig. 5). In Praunus flexuosus, the incubation time at $15^{\circ} \mathrm{C}$ was significantly longer ( $23 \pm 1 \mathrm{~d})$ than in $N$. integer $(19 \pm 1 \mathrm{~d})$.

There was a slight positive correlation between the number of released juveniles and female size in Neomysis integer at both temperatures (Fig. 6): $10^{\circ} \mathrm{C}(\mathrm{n}=$ 74) juvenile $=3.4 \times$ female -23.6 , correlation: $\mathrm{r}=0.59$;
Table 3. Neomysis integer. Comparison of reproduction at 2 temperatures $\left(10\right.$ and $\left.15^{\circ} \mathrm{C}\right)$ tested by ANCOVA. Range in female length was 9 to $16 \mathrm{~mm}$. 1-way ANCOVA; factor: temperature; covariable: standard length of females; dependent variable: number of juveniles. Homogeneity of variance: $F_{(1,136)}=1.01, \mathrm{p}=0.318 ;$ ANCOVA: $F_{(1,137)}=609, \mathrm{p}=0.015$

\begin{tabular}{|lrrr|}
\hline Factor & $\mathrm{n}$ & \multicolumn{2}{c|}{ Juveniles } \\
& & Mean & \multicolumn{1}{c|}{$\mathrm{SD}$} \\
\hline $10^{\circ} \mathrm{C}$ & 74 & 18.6 & 8.5 \\
$15^{\circ} \mathrm{C}$ & 106 & 22.6 & 14.7 \\
& & & \\
\hline
\end{tabular}

$15^{\circ} \mathrm{C}(\mathrm{n}=106):$ juvenile $=4.7 \times$ female -33.1 , correlation: $\mathrm{r}=0.54$.

At $10^{\circ} \mathrm{C}$ the smallest breeding female was $9.3 \mathrm{~mm}$, while at $15^{\circ} \mathrm{C}$ the smallest reproductive female was $2 \mathrm{~mm}$ smaller. A significant difference was found in the number of hatched juveniles at both temperatures (ANCOVA: Table 3). A mean of $19 \pm 6$ juveniles were released at $10^{\circ} \mathrm{C}$ and $22 \pm 15$ juveniles at $15^{\circ} \mathrm{C}$, with the highest number of juveniles (64) being hatched at $15^{\circ} \mathrm{C}$ and only half the number at $10^{\circ} \mathrm{C}$.

In Praunus flexuosus, no reproduction was observed at $10^{\circ} \mathrm{C}$ since the specimens reached a size of $20 \mathrm{~mm}$ at the age of $190 \mathrm{~d}$, but remained immature. At $15^{\circ} \mathrm{C}$ the smallest egg-carrying female was $15 \mathrm{~mm}$. A maximum of 32 juveniles were released from 1 marsupium. There was a positive correlation between the number of released juveniles and female size (Fig. 6): $15^{\circ} \mathrm{C}(\mathrm{n}=$ 83) : juveniles $=2.23 \times$ female -22.5 , correlation: $\mathrm{r}=0.54$ In comparison to Neomysis integer, Praunus flexuosus reproduced at a larger size, and therefore the eggs as well as the post-larval stages of $P$. flexuosus were 1 to $1.5 \mathrm{~mm}$ larger. However $N$. integer exceeded P. flexuosus in the number of juveniles released per brood (Fig. 6). N. integer was $7 \mathrm{~mm}$ in length at the first breeding at $15^{\circ} \mathrm{C}$. The number of released juvenile $N$. integer was twice as high as that of $P$. flexuosus. In $N$. integer, reproduction was significantly higher in combination with significantly lower incubation time at $15^{\circ} \mathrm{C}$ than at $10^{\circ} \mathrm{C}$. The smallest reproductive female P. flexuosus was $15 \mathrm{~mm}$. At $15^{\circ} \mathrm{C} \mathrm{P}$. flexuosus had a significantly longer incubation period than $N$. integer. The generation time (defined as the development within the marsupium and the postmarsupial development until maturation starts) of $P$. flexuosus is twice long as that of $N$. integer, $133 \mathrm{~d}$ compared to
Fig. 6. Neomysis integer and Praunus flexuosus. Reproduction of Neomysis integer at $10^{\circ} \mathrm{C}(\mathrm{n}=74)$
and $15^{\circ} \mathrm{C}(\mathrm{n}=106)$ and Praunus flexuosus at $15^{\circ} \mathrm{C}(\mathrm{n}=83)$ in relation to female size. Correlation coefficients were: $10^{\circ} \mathrm{C}, \mathrm{r}=0.59$ $(N$. integer $) ; 15^{\circ} \mathrm{C}, \mathrm{r}=0.54(N$. integer) and $\mathrm{r}=0.56$ ( $P$. flexuosus)

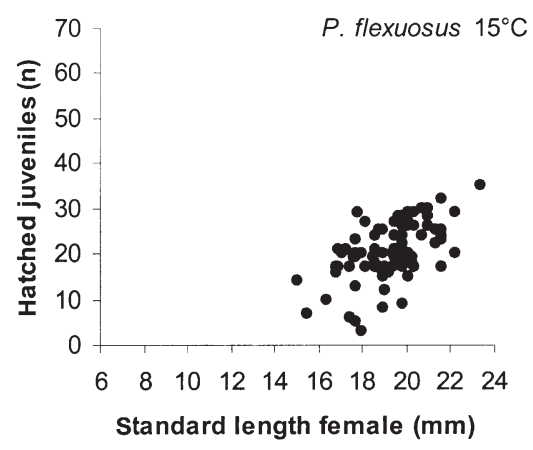


$69 \mathrm{~d}$. At this age $N$. integer is about $8 \mathrm{~mm}$ long and starts breeding, while $P$. flexuosus is twice this size when reproduction takes place. The reproduction rate (calculated by dividing the number of juveniles by the incubation time) for $\mathrm{N}$. integer at $15^{\circ} \mathrm{C}$ was markedly higher than at $10^{\circ} \mathrm{C}$. In comparison, $P$. flexuosus released a maximum of 0.8 juveniles $\mathrm{d}^{-1}$ while $N$. integer reached a maximum of 1.2 juveniles $\mathrm{d}^{-1}$.

\section{DISCUSSION}

The autecological aspects studied represent the combined effects of genetic, physiologic and abiotic factors. The results reveal a distinctive population structure and life history traits in both co-occurring mysids. The temperature dependence of the eco-physiological parameters were investigated in relation to ontogeny. The high impact of temperature on growth has been documented for other mysid species (Pezzack \& Corey 1979, 1982, Toda et al. 1983, 1984, 1987, Morgan 1985). For this study, the advantages of working in the laboratory were clear. For instance, growth parameters of several species could be determined and compared in detail under standardised experimental conditions instead of using growth rates of mysids estimated from successive field samples (Allen 1971, Mauchline 1985). This latter technique is very difficult because each generation consists of overlapping cohorts resulting from successive broods produced by individual females within the various generations.

\section{Growth in Neomysis integer}

The chosen temperatures represent the mean temperatures in spring and autumn $\left(10^{\circ} \mathrm{C}\right)$ and in summer $\left(15^{\circ} \mathrm{C}\right)$ in the outer Elbe estuary. In Neomysis integer, growth was observed from the post-larvae to the adult stages. The mysids were given excess food, and individual growth occurred continuously until they reached a length of $16 \mathrm{~mm}$ (Tattersall \& Tattersall 1951, Mauchline 1971a, 1980).

As size increased, the duration of the intermoult periods in Neomysis integer increased also. The intermoult period was longer at colder temperatures than at warmer temperatures, as noted earlier by Astthorsson \& Ralph (1984), but the characteristics of the growth factors differed in both studies. We found an increase in growth factors and growth rates at both temperatures during juvenile development, whereas Astthorsson \& Ralph (1984) found that the growth factors decreased steadily as the mysids grew and they did not detect an effect of temperature on the growth factor. These differences in the growth of $N$. integer possibly result from a greater number of observed specimens in our study, which allowed a more detailed evaluation of the data. In addition, the extended diet in our experiments probably fits better the nutritional needs of the mysids. Furthermore, in our study the water quality was kept constant by a flow-through aquarium system, in contrast to simply changing the water in the experimental beakers every $3 \mathrm{~d}$ as in Astthorsson \& Ralph's study. Our results indicate that the decrease in growth rate coincides with maturation. Since food is used not only for somatic growth but also for production of gonads, the consequence is that a large amount of energy is still being used, but is being allocated to reproduction at the expense of growth. Within the order Mysidacea, an abrupt decrease in growth rate is commonly observed immediately before maturation in $N$. intermedia and Metamysidopsis elongata (Clutter \& Theilacker 1971, Toda et al. 1984). In N. integer, an increase in variability of the intermoult period duration also occurred as juveniles matured. In egg-carrying females, intermoult periods and incubation time are identical because they do not moult while carrying eggs or larvae in the marsupium.

The effect of temperature on growth was pronounced in juvenile Neomysis integer: at low temperature $\left(10^{\circ} \mathrm{C}\right)$ they needed to moult more often to reach the same size as juveniles kept at $15^{\circ} \mathrm{C}$.

\section{Growth in Praunus flexuosus}

This study documents the first instance of growth rate measurements for Praunus flexuosus. We found, as with Neomysis integer, that temperature strongly affects the length of intermoult periods and growth factors. With increasing temperature, intermoult periods shortened and increment per moult increased. This is consistent with observations made on a few $P$. flexuosus specimens by Nouvel \& Nouvel (1939). The effect of temperature is greater on small individuals at $15^{\circ} \mathrm{C}$ : juveniles reached maturity at $15 \mathrm{~mm}$ within 3 to $4 \mathrm{mo}$; at $10^{\circ} \mathrm{C}$ they needed 4 to 5 mo to reach the same size, but without maturing.

\section{Comparison of growth in Neomysis integer and Praunus flexuosus}

The smaller species, Neomysis integer, reached maturity in a shorter time and at a smaller size than Praunus flexuosus. At $10^{\circ} \mathrm{C} \mathrm{P}$. flexuosus grew faster at all stages than $N$. integer, but matured at a larger size. There was no difference in growth rate at $15^{\circ} \mathrm{C}$ in the post-larval stages, but the amount of time required for maturation of $N$. integer was shorter. In contrast to $N$. 
Table 4. Neomysis integer and Praunus flexuosus. Comparison of temperature coefficients $\left(Q_{10}\right.$ values) of the growth rate of $N$. integer and $P$. flexuosus with those of other mysid species

\begin{tabular}{|lcccc|}
\hline Species & Developmental stage & $Q_{10}$ & Temperature $\left({ }^{\circ} \mathrm{C}\right)$ & Source \\
\hline Neomysis integer & $3-7 \mathrm{~mm}$ & $4.0-7.4$ & $10-15$ & This study \\
& $>7 \mathrm{~mm}$ & 1.3 & $10-15$ & This study \\
Praunus flexuosus & $3-15 \mathrm{~mm}$ & $1.0-3.1$ & $10-15$ & Toda et al. (1983) \\
N. intermedia & $>15 \mathrm{~mm}$ & 0.9 & $10-15$ & Gaudy \& Guérin (1979) \\
Leptomysis lingvura & Juvenile & 4.6 & $10-14$ & Gaudy \& Guérin (1979) \\
Hemimysis speluncola & Juvenile & 8.2 & $10-14$ & \\
\hline
\end{tabular}

integer, there was no distinctive decrease in growth rate when $P$. flexuosus reached maturity.

The growth curves of both species showed temperature-dependency, but growth was affected in different ways. At $10^{\circ} \mathrm{C}$ the growth factor of post-larval Neomysis integer was lower than at $15^{\circ} \mathrm{C}$, while post-larval growth factors in Praunus flexuosus displayed an opposite trend. This is similar to the results of Hartnoll (1978), who reported higher growth rates at higher temperatures in Rhithropanopeus harrisii (Decapoda) resulting from higher growth factors in combination with a higher frequency of moults. It should be noted that this means that $N$. integer was not the same size after the same number of moults at both temperatures. Conversely, $P$. flexuosus had the same body size after an equal number of moults at both temperatures, due to longer intermoult periods and higher growth factors at $10^{\circ} \mathrm{C}$ than at $15^{\circ} \mathrm{C}$. Other authors (Astthorsson \& Ralph 1984) did not find any temperature effect on growth factor. In addition, other similar growth studies on decapod crustaceans have shown that abiotic factors strongly influence the duration of intermoult periods but not growth factors (Chittleborough 1975, Mauchline 1985). The pronounced effect of temperature on $N$. integer would seem to be of advantage in maintaining population levels in its natural environment: fast growth at the higher temperatures in late spring may enhance the chance of survival for postlarval individuals, as a larger size potentially eases predation pressure.

Hartnoll \& Dalley (1981) described a regulation mechanism controlling the growth of Palaemon elegans (Decapoda) that minimised size variability during each intermoult period. This could describe the juvenile phase in Neomysis integer and Praunus flexuosus, in that both species moult synchronously, but their subsequent development is not synchronised.

Temperature dependence was greater in post-larval specimens that were not yet mature. Juvenile Neomysis integer attained temperature coefficients for growth rates as high as those in juvenile Leptomysis lingvura (Gaudy \& Guérin 1979). The temperature had less effect on the growth rate of juvenile Praunus flexuosus, for which the temperature coefficient was half that in $N$. integer but comparable to $Q_{10}$ values for juvenile $N$. intermedia (Toda et al. 1983) and juvenile Hemimysis speluncola (Gaudy \& Guérin 1979). Adult P. flexuosus showed a far lower temperature dependence (Table 4).

Faster growth of juveniles at higher temperatures increases productivity dramatically. The faster growth and early maturation in late spring and summer of Neomysis integer is of advantage in the early onset of reproduction and a longer reproduction period. In $P$. flexuosus, the biomass gain of the population primarily results from an increase in individual body weight and secondarily from an increased reproductive output. $P$. flexuosus reproduces at a larger size than $N$. integer, so that the eggs as well as the post-larval stages of $P$. flexuosus are 1 to $15 \mathrm{~mm}$ larger than for $N$. integer at a similar stage. Thus, the growth patterns appear to characterise 2 different life cycle strategies.

The sigmoid growth curve of Neomysis integer corresponds to those of other neritic mysids (Clutter \& Theilacker 1971, Mauchline 1985), while the growth curve of Praunus flexuosus fits a more saturated curve. However, the growth parameters of both species deviate from those Mauchline $(1976,1977)$ suggested for the growth of crustaceans in general. No significant negative linear relationship of the log growth factor on body size was detected for the mysids. In contrast to a logarithmic decline, an increase in the growth factor was found in the progression of juvenile stages of $N$. integer. Childress \& Price (1978) also noted a deviation in the growth patterns proposed by Mauchline in a bathypelagic mysid, Gnathophausia ingens.

Growth rates of mysids estimated from field data often underestimate the potential growth of the individuals. In many studies, growth is averaged over the whole population without taking into account developmental stage (Bremer \& Vijverberg 1982, Toda et al. 1983, Irvine et al. 1995). More accurate results can be achieved if a population is divided into juveniles and adults. Mean growth rates of mysids in Scotland (Astthorsson \& Ralph 1984, Astthorsson 1987) and The 
Netherlands (Mees et al. 1994) correspond with our laboratory data (Table 5). Our laboratory data provide a more detailed picture of growth during the developmental stages and enable a better comparison because of the standardised experimental conditions. On the other hand, our data lack the effect of natural variability in the availability and diversity of food and temperature in the field. In future work, a combination of laboratory studies and field work could optimise the knowledge on growth of mysids.

\section{Reproduction}

The reproduction rate of Neomysis integer increased at higher temperatures due to declining incubation periods plus an increasing number of juveniles released. The number of hatched $N$. integer increased with increasing size of the females. The brood size was a little smaller than those found in field observations (Vorstman 1951, Mauchline 1971a, 1973, Parker 1979, Parker \& West 1979, Mees et al. 1994), but this differ- ence is likely to be due to different methods of brood size determination. In this study, the number of released juveniles were counted in contrast to counting the eggs and larvae in the marsupium, while meaning mortality during marsupial development was ignored.

At the higher temperature, the number of released juveniles per brood was highly variable, probably due to the successive oviposition of the females (Kinne 1955). In this study it could not be excluded that females undergoing second and third oviposition were investigated, and that these females released less juveniles than females breeding for the first time. In addition to brood size, Wittmann (1984) describes temperature-dependent incubation time as a key factor in variation of the length and onset of breeding as well as the frequency of the successive broods. Temperature dependency of the incubation time for $N$. integer is illustrated by a comparison of data from various studies (Kinne 1955, Vlasblom \& Elgershuizen 1977, Irvine et al. 1995, this study) in Fig. 7. A negative linear relationship exists between incubation time and temperature.

Table 5. Neomysis integer and Praunus flexuosus. Comparison of growth rates in field and laboratory studies

\begin{tabular}{|c|c|c|c|c|c|}
\hline Species & $\begin{array}{l}\text { Developmental } \\
\text { stage }\end{array}$ & $\begin{array}{l}\text { Growth rate } \\
\left(\mathrm{mm} \mathrm{d}^{-1}\right)\end{array}$ & $\begin{array}{c}\text { Temperature } \\
\left({ }^{\circ} \mathrm{C}\right)\end{array}$ & Study & Source \\
\hline \multirow[t]{4}{*}{ N. integer } & $3-7 \mathrm{~mm}$ & $0.05 \pm 0.01-0.09 \pm 0.02$ & 10 & \multirow[t]{4}{*}{ Laboratory } & \multirow[t]{4}{*}{ This study } \\
\hline & & $0.12 \pm 0.04-0.19 \pm 0.08$ & 15 & & \\
\hline & $8-12 \mathrm{~mm}$ & $0.03 \pm 0.01-0.08 \pm 0.03$ & 10 & & \\
\hline & & $0.03 \pm 0.02-0.09 \pm 0.05$ & 15 & & \\
\hline N. integer & $2-14 \mathrm{~mm}$ & $0.13-0.16$ & May-Oct & Slotermeer & Bremer \& Vijverberg (1982) \\
\hline \multirow[t]{4}{*}{ N. intermedia } & Juveniles & 0.018 & 3 & \multirow[t]{4}{*}{ Laboratory } & \multirow[t]{4}{*}{ Toda et al. (1984) } \\
\hline & & 0.21 & 20 & & \\
\hline & Adults & 0.006 & 3 & & \\
\hline & & 0.05 & 25 & & \\
\hline \multirow[t]{8}{*}{ N. integer } & Summer generation & & & \multirow[t]{6}{*}{ Ythan Estuary } & \multirow[t]{8}{*}{ Astthorsson \& Ralph (1984) } \\
\hline & Juveniles & $0.13-0.16$ & & & \\
\hline & Adults & $0.03-0.06$ & & & \\
\hline & Winter generation & & & & \\
\hline & Juveniles & & $0.1-0.13$ & & \\
\hline & Adults & $0.03-0.06$ & & & \\
\hline & $3-13 \mathrm{~mm}$ & $0.02-0.09$ & 9 & \multirow{2}{*}{ Laboratory } & \\
\hline & $3-12 \mathrm{~mm}$ & $0.03-0.15$ & 16 & & \\
\hline \multirow[t]{3}{*}{ N. integer } & Juveniles + adults & $0.1-0.13$ & Sep/Nov & \multirow[t]{3}{*}{ Westerschelde } & \multirow[t]{3}{*}{ Mees et al. (1994) } \\
\hline & Juveniles & $0.1-0.13$ & Spring/summer & & \\
\hline & Adults & $0.03-0.06$ & Spring/summer & & \\
\hline \multirow[t]{4}{*}{ N. integer } & Mean & 0.08 & May-Sep & \multirow[t]{4}{*}{ Hickling Broad } & \multirow[t]{4}{*}{ Irvine et al. (1995) } \\
\hline & & Max. 0.16 & & & \\
\hline & & 0.07 & Sep-Oct & & \\
\hline & & 0.03 & Nov-Apr & & \\
\hline \multirow[t]{2}{*}{ P. flexuosus } & Juveniles & $0.13-0.16$ & 11 & \multirow[t]{2}{*}{ Iceland } & \multirow[t]{2}{*}{ Astthorsson (1987) } \\
\hline & Mean & $0.05-0.007$ & 9 & & \\
\hline \multirow[t]{4}{*}{ P. flexuosus } & $3-14 \mathrm{~mm}$ & $0.08 \pm 0.03-0.14 \pm 0.05$ & 10 & \multirow[t]{4}{*}{ Laboratory } & \multirow[t]{4}{*}{ This study } \\
\hline & & $0.12 \pm 0.05-0.17 \pm 0.05$ & 15 & & \\
\hline & $15-24$ & $0.03 \pm 0.02-0.09 \pm 0.04$ & 10 & & \\
\hline & & $0.03 \pm 0.03-0.1 \pm 0.03$ & 15 & & \\
\hline
\end{tabular}




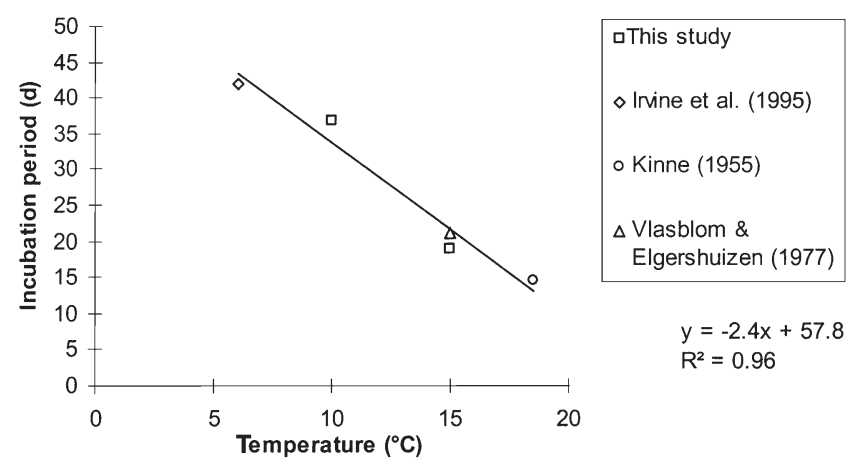

Fig. 7. Neomysis integer. Relationship between incubation time and temperature for mysids in various studies

The overall reproduction rate of Neomysis integer was double that of Praunus flexuosus due to the fact that $P$. flexuosus had longer incubation times and released fewer juveniles than $N$. integer. Developmental time in the marsupium for $P$. flexuosus was similar to that found in Danish and French waters (Blegvad 1922, Nouvel \& Nouvel 1939) for the same species, and Berrill (1971) found incubation times of similar duration but at a colder temperature $\left(13.5^{\circ} \mathrm{C}\right)$.

\section{Life cycle}

The shorter generation time of Neomysis integer compared to Praunus flexuosus, caused mainly by highly temperature-dependent incubation periods and post-marsupial development time, suggests that $N$. integer will produce more generations per year than $P$. flexuosus. At warm temperatures of $15^{\circ} \mathrm{C}$, the generation time of $N$. integer is $70 \mathrm{~d}$. Fertilised eggs were released from the marsupium after $19 \mathrm{~d}$ incubation as post-larvae, and maturity is reached in $50 \mathrm{~d}$. Water temperatures in the Elbe estuary range between 15 and $17^{\circ} \mathrm{C}$ from June to September, so that 2 summer generations can be predicted. In $P$. flexuosus, the generation time is $133 \mathrm{~d}$, the embryos develop for $23 \mathrm{~d}$ in the marsupium, and the juveniles grow $110 \mathrm{~d}$ before maturity. This species should therefore only manage 1 generation during a single summer. The proposed series of generations derived from the results of the laboratory data are consistent with the results of several field studies. Two summer generations and 1 winter generation per year were found in $N$. integer (Vorstman 1951, Mauchline 1971a, Beattie \& de Kruijf 1978, Borghouts 1978, Bremer \& Vijverberg 1982). In Lough Furnance (Ireland) and Lough Etive (Scotland), no separate generations persist because gravid females were also found in autumn so that recruits appeared in December (Mauchline 1971a, Parker 1979, Parker \& West 1979). In the Westerschelde (The Netherlands), no reproduction occurs during the winter (Mees et al. 1994). There, the breeding season starts in April at $10^{\circ} \mathrm{C}$ and ends in October with temperatures below $10^{\circ} \mathrm{C}$. Again only 2 generations per year, 1 summer and 1 winter generation, were found in $P$. flexuosus in the North Sea and the Baltic Sea (Blegvad 1922, Zimmer 1933). In some areas a small proportion of $P$. flexuosus females born during summer manage to spawn in autumn of the same year (Tattersall \& Tattersall 1951, Mauchline 1971b). The winter generation of $N$. integer and $P$. flexuosus hatched in autumn grow slower at the lower temperatures, taking 5 and 6 mo of development, respectively, to mature by the next spring. There are also clear differences in the sequence of generations of $N$. integer and $P$. flexuosus based on the developmental time, time of maturity and number and size of the offspring. Within each species these parameters are not only affected by temperature but are also determined by the nutritional situation (Sastry 1983), which has not been studied here.

Parker \& West (1979) interpreted the life history of Neomysis integer in a brackish Lough in Ireland as an r-selection strategy. They used the concept of $\mathrm{r}$ - and kselected populations in order to distinguish between different life history traits according to MacArthur \& Wilson (1967) and Pianka (1970). In our study, N. integer had short generation times, relatively high numbers of individuals per brood and several successive ovipositions, once again reflecting an r-strategy. In contrast, Praunus flexuosus, with its longer generation times and lower numbers of juveniles per brood, corresponds more closely to the k-strategy. This is supported by findings of Muus (1967), who found both species shoaling together but with $P$. flexuosus less numerous than $N$. integer. This leads to some conclusions about the coexistence of these species in brackish-water habitats. We interpret these findings as indicating that, in order to minimise competitive interactions, the species have seasonal segregation of their reproductive periods. The segregation is possible because of the differences in temperature-dependent growth rates, development time, number of moults, and intermoult period. When comparing a population study in Lough Etive (in which during February and March P. flexuosus and N. integer coexisted, but in the following months separated spatially, with $P$. flexuosus disappearing by September: McLusky \& Heard 1971) with our laboratory results, it has to be taken into account that other factors which also influence coexistence were not addressed in our study. Specifically, different resource requirements, nutrient availability, and migratory patterns could all structure the populations and affect interspecific competition. 
Acknowledgements. Special thanks are extended to the crew members of the Uthörn, Katja Broeg, Alfonso Cugat, Jutta Nast, Nalz Peters, Ulrike Pein, Mara Pezenburg, and Sabine Prinage for their assistance in the field and the laboratory. We thank Dr. Ute Wilhelmsen for helpful discussions and critical reading of the manuscript and Andy Casper and Christine Barnard for correcting the language. This project has been financially supported by the German Science Foundation (DFG: GR 382/3-1).

\section{LITERATURE CITED}

Allen KR (1971) Relation between production and biomass. J Fish Res Board Can 28:1573-1581

Astthorsson OS (1987) Records and life history of Praunus flexuosus (Crustacea: Mysidacea) in Icelandic waters. J Plankton Res 9:955-964

Astthorsson OS, Ralph R (1984) Growth and moulting of Neomysis integer (Crustacea: Mysidacea). Mar Biol 79:55-61

Beattie D, de Kruijf H (1978) Population dynamics and biomass production of Neomysis integer in the Bergumermeer. Verh Int Ver Limnol 20:2566-2571

Berrill M (1971) The embryonic development of the avoidance reflex of Neomysis americana and Praunus flexuosus. Anim Behav 19:707-713

Blegvad H (1922) On the biology of some Danish gammarids and mysids. Rep Dan Biol Stn 28:1-103

Borghouts C (1978) Population structure and life-cycle of Neomysis integer (Leach) (Crustacea, Mysidacea) in two types of inland waters. Verh Int Ver Limnol 20:2561-2565

Bremer P, Vijverberg J (1982) Production, population biology and diet of Neomysis integer (Leach) in a shallow Frisian lake (The Netherlands). Hydrobiologia 93:41-50

Childress J, Price MH (1978) Growth rate of the bathypelagic crustacean Gnathophausia ingens. Dimensional growth and population structure. Mar Biol 50:47-62

Chittleborough RG (1975) Environmental factors affecting growth and survival of juvenile western rock lobster Panulirus longipes (Milne-Edwards). Aust J Mar Freshw Res 26:177-196

Clutter R, Theilacker GH (1971) Ecological efficiency of a pelagic mysid shrimp: estimates from growth, energy budget, and mortality studies. Fish Bull (Wash DC) 69:93-115

Fulton RS (1982a) Preliminary results of an experimental study of the effects of mysids predation on estuarine zooplankton community structure. Hydrobiologia 93:79-84

Fulton RS (1982b) Predatory feeding of two marine mysids. Mar Biol 72:183-191

Gaudy R, Guérin JP (1979) Écophysiologie comparée des mysidacés Hemimysis speluncola et Leptomysis lingvura. Action de la température sur la croissance en élevage. J Exp Mar Biol Ecol 38:101-119

Hartnoll RG (1978) The effect of salinity and temperature on the post-larval growth of the crab Rhithropanopeus harrisii. In: McLusky DS, Berry AJ (eds) Physiology and behaviour of marine organisms. Proc 12th Eur Mar Biol Symp. Pergamon Press, New York, p 349-358

Hartnoll RG, Dalley R (1981) The control of size variation within instars of a crustacean. J Exp Mar Biol Ecol 53: 235-239

Irvine K, Snook D, Moss B (1995) Life histories of Neomysis integer, and its copepod prey, Eurytemora affinis, in a eutrophic and brackish shallow lake. Hydrobiologia 304: $59-76$

Kinne O (1955) Neomysis vulgaris, eine autökologische Studie. Biol Zentbl 74:160-202
Lasenby DC, Langford RR (1972) Growth, life history, and respiration of Mysis relicta in an Arctic and temperate lake. J Fish Res Board Can 29:1701-1708

MacArthur RH, Wilson EO (1967) The theory of island bio graphy. Princeton University Press, Princeton, NJ

Mauchline J (1971a) The biology of Neomysis integer Crustacea, Mysidacea. J Mar Biol Assoc UK 51:347-354

Mauchline J (1971b) The biology of Praunus flexuosus and P. neglectus Crustacea Mysidacea. J Mar Biol Assoc UK 51: 641-652

Mauchline J (1973) The broods of British Mysidacea Crustacea. J Mar Biol Assoc UK 53:801-817

Mauchline J (1976) The Hiatt growth diagramm of Crustacea. Mar Biol 35:79-84

Mauchline J (1977) Growth of shrimps, crabs and lobsters an assessment. J Cons Int Explor Mer 37:162-169

Mauchline J (1980) The biology of mysids and euphausids (Crustacea, Mysidacea). Adv Mar Biol 18:3-317

Mauchline J (1985) Growth in mysids and euphausids. Crustac Issues 3:337-355

McLusky D (1979) Some effects of salinity and temperature on the osmotic and ionic regulation of Praunus flexuosus (Crustacea, Mysidacea) from Isefjord. Ophelia 18:191-203

McLusky DS, Heard V (1971) Some effects of salinity on the mysid Praunus flexuosus. J Mar Biol Assoc UK 51:709-715

Mees J, Cattrijsse O, Hamerlynck O (1993) Distribution and abundance of shallow-water hyperbenthic mysids and euphausiids in the Voordelta and the Westerschelde, Southwest Netherlands. Cah Biol Mar 34:165-186

Mees J, Abdulkerim Z, Hamerlynck O (1994) Life history, growth and production of Neomysis integer in the Westerschelde Estuary. Mar Ecol Prog Ser 109:43-57

Morgan MD (1985) Growth and its relationship to reproduction in Mysis relicta. Crustac Issues 3:235-250

Muus BJ (1967) The fauna of Danish estuaries and lagoons. Medd Dan Fisk Havunders N Ser 5:1-316

Nicol EAT (1935) Ecology of a salt-marsh. J Mar Biol Assoc UK 20:203-261

Nouvel H, Nouvel L (1939). Observations sur la biologie d'une mysis: Praunus flexuosus. Bull Instit Océanogr (Monaco) 761:1-10

Parker M (1979) Neomysis integer (Leach) (Crustacea: Mysidacea) records and distribution in Ireland. Ir Nat J 19: $339-342$

Parker M, West B (1979) The natural history of Neomysis integer in Lough Furnace, Co. Mayo, a brackish lough in the west of Ireland. Estuar Coast Mar Sci 8:157-167

Petersen CG (1922) Report of the Danish biological station. Rep Dan Biol Stn 28:1-115

Pezzack DS, Corey S (1979) The life history and distribution of Neomysis americana (Smith) (Crustacea, Mysidacea) in Passamaquoddy Bay. Can J Zool 57:785-793

Pezzack DS, Corey S (1982) Effects of temperature and salinity on immature and juvenile Neomysis americana (Smith) (Crustacea, Mysidacea). Can J Zool 60:2725-2727

Pianka ER (1970) On r- and K- selection. Am Nat 104:592-597

Rasmussen E (1973) Systematics and ecology of the Isefjord marine fauna (Denmark). Ophelia 11:1-507

Sastry AN (1983) Ecological aspects of reproduction. In: Vernberg JF, Vernberg WB (eds) The biology of Crustacea. Academic Press, New York, p 179-281

Tattersall WM, Tattersall OS (1951) The British Mysidacea. Ray Society, London

Toda H, Nishizawa S, Takahashi M, Ichimura S (1983) Temperature control on the post-embryonic growth of Neomysis intermedia Czerniawsky in a hypereutrophic temperate lake. J Plankton Res 5:377-392 
Toda H, Takahashi M, Ichimura S (1984) The effect of temperature on the post-embryonic growth of Neomysis intermedia Czerniawsky (Crustacea, Mysidacea) under laboratory conditions. J Plankton Res 6:647-661

Toda H, Arima T, Takahashi M, Ichimura S (1987) Physiological evaluation of temperature effect on the growth processes of the mysid, Neomysis intermedia (Czerniawsky). J Plankton Res 9:51-63

Vlasblom A, Elgershuizen J (1977) Survival and oxygen consumption of Praunus flexuosus and Neomysis integer and

Editorial responsibility: Otto Kinne (Editor),

Oldendorf/Luhe, Germany embryonic development of the latter species in different temperature and chlorinity combinations. Neth J Sea Res 11:305-315

Vorstman AG (1951) A year's investigations on the life cycle of Neomysis vulgaris (Thompson). Ver Int Ver Theor Limnol 11:437-445

Wittmann KJ (1984) Ecophysiology of marsupial development and reproduction in Mysidacea (Crustacea). Oceanogr Mar Biol Annu Rev 22:393-428

Zimmer C (1933) Mysidacea. Tierwelt N u Ostsee 22-69

Submitted: April 2, 2001; Accepted: November 8, 2001

Proofs received from author(s): May 17, 2002 